\title{
A COGNITIVE RATIONALE FOR A PROBLEM-BASED U.S. HISTORY SURVEY
}

\author{
Charles T. Wynn \\ Kennesaw State University
}

In recent years, calls for reform of the coverage-based history survey course have been numerous, ${ }^{1}$ as have suggestions for new instructional approaches designed to promote more active, meaningful, and applicable learning among students. Much of the "Scholarship on the Teaching and Learning" of history (often called SoTL) within a survey course context comes through a focused disciplinary lens. Illustrative of the discussion is David Pace's call for a cognitive frame of reference within this focus through two broad questions: "What do students bring to the history classroom that might have a major impact on their learning?" and "What mental operations and procedures must [students] master in order to think historically?"2 Questions of this type, as well as the fundamental belief that historical thinking is crucial in the teaching and learning of history in a survey course context, have guided SoTL scholars such as David Pace, Sam Wineburg, Lendol Calder, and Robert Bain to apply cognitive learning dynamics to help explain how students may acquire "habits of mind" of the historian. ${ }^{3}$ Historical thinking is broadly defined as the reading, analysis, and writing that is necessary to develop an understanding of the past. ${ }^{4}$ Developing these skills among survey students calls for domain-specific scaffolds within the context of historical inquiry, ${ }^{5}$ under the assumption that the knowledge and analytical skills gained from such practice will be useful in a broader general education context as students

\footnotetext{
${ }^{1}$ Stephen D. Andrews, "Structuring the Past: Thinking About the History Curriculum," The Journal of American History, 95 (March 2009), 1094-1101; Lendol Calder, "Uncoverage: Toward a Signature Pedagogy for the History Survey," The Journal of American History, 93 (March 2006), 1358-1370; Julie R. Jeffrey, "The Survey, Again," OAH Magazine of History, 17 (Apri1 2003), 52-54; Joel M. Sipress and David J. Voelker, "The End of the History Survey Course: The Rise and Fall of the Coverage Model," The Journal of American History, 97 (March 2011), 1050-1066; Peter Stearns, Meaning Over Memory: Recasting the Teaching and Culture of History (Chapel Hill: University of North Carolina Press, 1994).

${ }^{2}$ David Pace, "The Amateur in the Operating Room: History and the Scholarship of Teaching and Learning," The American Historical Review, 109 (October 2004), 4.

${ }^{3} \mathrm{Pace}$, "The Amateur in the Operating Room;" Sam Wineburg, Historical Thinking and Other Unnatural Acts: Charting the Future of Teaching the Past (Philadelphia: Temple University Press, 2001); Lendol Calder, "Uncoverage;" Robert Bain, "Into the Breach: Using Research and Theory to Shape History Instruction," Journal of Education, 189 (September 2008), 159-167.
}

${ }^{4}$ National History Education Clearing House, "What Is Historical Thinking?" http://teachinghistory.org/ historical-thinking-intro (accessed Dec. 14, 2012).

5Bain, "Into the Breach." 
continue their educational careers, and as they take their place as adult participatory citizens. Peter Stearns framed this connection between the interpretive and analytical skills gained through the practice of historical thinking and effective citizenship when he addressed the question- "Why study history?" Stearns wrote:

Historical study, in sum, is crucial to the promotion of that elusive creature, the well-informed citizen. It provides basic factual information about the background of our political institutions and about the values and problems that affect our social well-being. It also contributes to our capacity to use evidence, assess interpretations, and analyze change and continuities. No one can ever quite deal with the present as the historian deals with the past-we lack the perspective for this feat; but we can move in this direction by applying historical habits of mind, and we will function as better citizens in the process. ${ }^{6}$

Given the above assertion, the development of historical thinking skills becomes critical in a general education context, considering a majority of students who populate survey history courses are not, nor will be, history majors. Assuming these students develop historical thinking skills to some competent degree over a semester or two, the question arises to what extent will they be able to maintain and apply domain-specific knowledge and reasoning skills beyond the context of the survey course? Robert Bain posed a similar question:

While I have been arguing that an environment rich in historically grounded scaffolds enables deeper thinking, I have no idea what happens when students move into other settings. Does any of this have staying power, or is it merely contextualized to "that is how we studied history in our freshman year?"?

Christian Laville summarized this challenge in regards to the application of historical thinking to the broader real-world problem-solving inherent in participatory citizenship when he stated:

First, our students as adults will rarely be called upon to bring these faculties to bear upon versions of prefabricated history, but more often upon the great variety of issues, most of them unforeseeable, that will

${ }^{6}$ Peter Stearns, "Why Study History?" American Historical Association, August 24, 2012, http://www.historians.org/pubs/free/WhyStudyHistory.htm (accessed August 24, 2012), paragraph 20.

${ }^{7}$ Bain, "Into the Breach," 166. 
constitute their social reality. And second the conceptual and methodological tools they acquire or develop in our schools must be as durable as possible, preferably for lifelong use. In short we must not forget that these pupils we are preparing in class will be less likely, as adults, to deal with history texts than to use their skills as citizens in the identification of social problems, the analysis of areas of conflict, the rational calculation of risk and rewards, and the weighing of competing interests, and in their personal decisions on the issues of the day. ${ }^{8}$

Jan Inglis and Margaret Steele posited that the majority of our population is in transition from Piaget's formal operational thought to postformal operations and that a large gap exists between the societal challenges we face and our collective capacity (reasoning ability, emotional maturity, and inter-societal deliberative capacity) to respond to these challenges." They supported their position by citing Shawn Rosenberg's argument that most citizens do not have the capacity to engage in deliberative democracy, ${ }^{10}$ and then they called for pedagogical approaches and support systems to help individuals navigate the gap between formal thinking and the postformal cognitive operations that are needed to deal effectively with current and future problems and issues. ${ }^{11}$

How then can we structure the survey history course to help fill this cognitive gap, as well as the gap that might exist between the guided practice of historical habits of mind among students and the purposeful application of historical thinking and other advanced cognitive skills to the broader context of participatory citizenship and related personal decisions on issues? This article addresses this question as follows: First, by examining cognitive skills that are common among students entering a U.S. history survey course that might impact problem-solving and decision-making (What are students coming in with?); second, by describing specific targets of advanced cognition inherent in adult problem-solving and decision-making (Where do we want to take them?); and third, by offering a problem-based instructional model and sample activity

${ }^{8}$ Christian Laville, "Historical Consciousness and Historical Education: What to Expect from the First for the Second," in Theorizing Historical Consciousness, ed. Peter Seixas (Toronto: University of Toronto Press, 2004), 166-167.

${ }^{9} \mathrm{Jan}$ Inglis and Margaret Steele, "Complexity Intelligence and Cultural Coaching: Navigating the Gap Between Our Societal Challenges and Our Capacities," Integral Review, 1 (2005), 36-46.

\footnotetext{
${ }^{10}$ Shawn Rosenburg, "Reconstructing the Concept of Deliberative Democracy," Center for the Study of Democracy Working Papers (January 2004), http://escholarship.org/uc/item/2rd8m486 (accessed January 21, 2013).
}

"Inglis and Steele, "Complexity Intelligence and Cultural Coaching." 
(using Woodrow Wilson and the Paris Peace Conference) designed to advance these cognitive skills (How do we get them there?).

\section{What Are Students Coming in With? \\ What Cognitive Skills Do Students Possess as They Enter Their U.S. History Survey?}

The thinking dynamics outlined in Jean Piaget's Periods of Cognitive Development provide a useful framework to understand student thinking limitations that might be common in a history survey course. Students who are primarily concrete thinkers (the third of Piaget's periods) can apply logical operations to problem-solving in concrete situations, but they are limited in applying logical operations to abstractions, hypothetical situations, or past events. ${ }^{12}$ Such operations still require physical manipulation of concrete objects or visible situations. ${ }^{13}$ Simply put, many survey history students require multiple concrete examples of abstract concepts, ideas, and events, in order to construct a useful/applicable understanding.

In contrast, formal thinking (Piaget's fourth and final period) allows students to manipulate logical relationships among abstract propositions, think logically about possible states of affairs, and use the experimental method to test hypotheses, ${ }^{14}$ skills that are absolutely necessary in most survey history courses, and in abstract problemsolving in general. However, abstract reasoning is not automatically acquired by everyone. Piaget posited that even adults might think like concrete operation children without "cognitive nourishment and intellectual stimulation." 15 If students have not had significant abstract problem-solving experiences prior to entering their survey course, they might lack formal operational skills.

Students who have gained formal reasoning skills often fail to use them and fall back on intuitive thinking (if it feels right, it's right) ${ }^{16}$ when confronting a complex problem or issue in a survey course due to the intellectual discipline and practice

\footnotetext{
${ }^{12}$ Charles Wynn, "Promoting Cognitive Growth through Problem-based Instruction in a First-year Learning Community," Journal of Learning Communities Research, 5 (November 2010), 5-16.

${ }^{13}$ David Mosely, Frameworks for Thinking: A Handbook for Teaching and Learning (Cambridge: Cambridge University Press, 2005).
}

${ }^{14}$ Barbel Inhelder and Jean Piaget, The Growth of Logical Thinking from Childhood to Adolescence: An Essay on the Construction of Formal Operational Structures (New York: Basic Books, 1958).

${ }^{15}$ Jean Piaget, "Intellectual Evolution from Adolescence to Adulthood," Human Development, 15 (1972), $1-12$.

${ }^{16}$ Kathleen Berger, The Developing Person Through the Life Span (New York: Worth, 2008). 
required to apply analytical reasoning successfully. ${ }^{17}$ Even experienced formal thinkers might have difficulty with complex problems and issues in a survey history course. Jan Sinnott described the limitations of formal thinking in dealing with multidimensional problems as a "lack of fit between formal operations and reality," recognizing the discrepancy but continuing to force a solution within a closed system. Complex problem-solving requires a high level of intellectual discipline to break away from a "closed systems" perspective. Students must come to recognize the inadequacy of the formal thinking system in order to prompt a search for a "best fit" system of complex problem-solving. ${ }^{19}$ The problem-based model and sample activity provided in this article are designed to guide students to discover and practice new systems of thinking that, if acquired, will serve them well in systematically addressing the problems and issues they will confront in a problem or issue-based survey history course and in dealing with the complex problems they will face as citizens.

\section{Where Do We Want to Take Them? \\ What Specific Targets of Advanced Cognition Are Involved in Complex Problem-Solving and Adult Decision-Making?}

These advanced thinking operations occur in a proposed "postformal" stage of reasoning in which adults develop more advanced cognitive structures in order to solve complex problems successfully. ${ }^{20}$ Sebby and Papini described the transition between

${ }^{17}$ Laurence Steinberg, "Risk Taking in Adolescence: New Perspectives from Brain and Behavioral Sciences," Current Directions in Psychological Sciences, 16 (April 2007), 55-59.

${ }^{18} \mathrm{Jan}$ Sinnott, The Development of Logic in Adulthood: Postformal Thought and Its Applications (New York: Plenum Press, 1998), 36.

${ }^{19}$ Tbid.

${ }^{20}$ Patricia K. Arlin, "Cognitive Development in Adulthood: A Fifth Stage?," Developmental Psychology, 11 (September 1975), 602-606; Patricia K. Arlin, "Adolescent and Adult Thought: A Structural Interpretation," in Beyond Formal Operations: Late Adolescent and Adult Cognitive Development, ed. Michael L. Commons, Jan D. Sinnott, Francis A. Richards, and Cheryl Armon (New York: Praeger, 1984), 256-271; Michael M. Basseches, Dialectical Thinking and Adult Development (Norwood, NJ: Ablex, 1984); Michael Basseches, "Dialectical Thinking as an Organized Whole: Comments on Irwin and Kramer," in Adult Development Volume 1: Comparisons and Applications of Developmental Models, ed. M.L. Commons, Jan D. Sinnott, Francis A. Richards, and Cheryl Armon (New York: Praeger, 1989), 161-178; Michael L. Commons and Sara N. Ross, "What Postformal Thought Is, and Why It Matters, World Futures, 64 (2008), 321-329; Gisela Labouvie-Vief, "Intelligence and Cognition," in Handbook of the Psychology of Aging, $2^{\text {nd }}$ ed., ed. James E. Birren and Klaus W. Schaie (New York: Van Nostrand Reinhold, 1985); William G. Perry, Jr., Forms of Intellectual and Ethical Development in the College Years: A Scheme (New York: Holt, Rinehart and Winston, 1970); Klaus F. 
formal and postformal thinking as "a progression in thinking from dualistic or absolutist thought (truth vs. falsehood) to more subjectively determined modes of thinking in which the relativistic and/or dialectical nature of knowledge is more thoroughly understood." ${ }^{21}$ Postformal thinking involves a relativistic approach to problem solving through which individuals recognize that real-world, complex problems often have multiple conflicting ideas about what is true and relevant, and consider the context and unique circumstances of a problem as they construct solution alternatives, and select the "truth" within a particular circumstance. ${ }^{22}$ These complex or ill-structured problems also require a dialectical inquiry system, the most advanced cognitive processes associated with postformal thinking. ${ }^{23}$ Several cognitive researchers have proposed such a system that, in part, emanates as individuals seek to resolve contradictions. ${ }^{24}$ Dialectical thinkers thrive on inconsistencies and contradictions as they recognize and apply multiple cognitive systems to seek resolutions that lead to higher levels of understanding and a broader, more complex, organizational structure of cognition. ${ }^{25}$ Dialectical thinkers not only consider diverse even opposing positions as they solve problems and make decisions, but they recognize that many problems do not have correct answers and understand that change is fundamental in the dialectical analysis of complex problems and issues. Change in this context refers to changes in thinking systems, as described above, and recognition that change affects the dynamics of the problem or issue at hand. ${ }^{26}$ Michael Basseches posited that exposure to diverse perspectives inherent in complex problems and issues along with opportunities for

${ }^{20}$ (...continued)

Riegel, "Toward a Dialectical Theory of Development," Human Development, 18 (1975), 50-64; Jan D. Sinnott, "A Model for Solution of Ml-Structured Problems: Implications for Everyday and Abstract Problem Solving," in Everyday Problem Solving: Theory and Applications, ed. Jan D. Sinnott (New York: Praeger, 1989); Sinnott, The Development of Logic in Adulthood.

${ }^{21}$ Richard A. Sebby and Dennis R. Papinni, "Postformal Reasoning During Adolescence and Young Adulthood: The Influence of Problem Relevancy," Adolescence, 29 (Summer 1994), 389.

${ }^{22}$ Sinnott, The Development of Logic in Adulthood.

${ }^{23}$ Ibid.

${ }^{24}$ Riegel, "Toward a Dialectical Theory of Development;" Basseches, Dialectical Thinking and Adult Development; Basseches, "Dialectical Thinking as an Organized Whole."

${ }^{25}$ David Y.F. Ho, "Dialectical Thinking: Neither Eastern nor Western," American Psychologist, 55:9 (September 2000), 1064-1065.

${ }^{26}$ Michael Basseches, "The Development of Dialectical Thinking as an Approach to Integration," Integral Review, 1 (2005), 47-63. 
careful, critical reflections as part of a modeling process might facilitate a reorganization of formal operations within the more adequate organization of thinking. ${ }^{27}$ Therefore, ill-structured, real world problems must have a primary focus in any course in which the promotion of dialectical reasoning is a primary goal. Here lies the rationale for a problem-based survey history course.

Social learning theory provides a framework for the type of modeling called for by Basseches. Lev Vygotsky described the social learning process as one in which the environment should stimulate the person to perform at a level slightly in advance of his/her current developmental level or zone of proximal development (ZPD) ${ }^{28} \mathrm{He}$ defined ZPD as "the distance between the actual developmental level as determined by independent problem solving and the level of potential development as determined through problem solving under adult guidance or in collaboration with more capable peers." 29 The importance of the instructor as not only a guide, but as a model, is central to the cognitive scaffolding necessary to promote advanced problem-solving among students in a survey history course context. Instructors must model how they recognize, select, and apply domain specific cognitive skills (historical thinking and others) and broader thinking systems (intuitive, formal, relativistic, dialectical) based on the characteristics of the problem at hand, then must guide students through a reflective process in which they judge which systems were most useful or successful, and why.

\section{How Do We Get Them There? \\ A Problem-Based Instructional Model for the U.S. History Survey Course}

Problem-based learning (PBL) is an instructional approach well suited to helping survey history students develop and apply postformal thinking skills, and is defined as "focused, experiential learning (minds-on, hands-on) organized around the investigation of and resolution of messy, real world problems. PBL--which incorporates two complementaryprocesses, curriculum organization and instructional strategy-includes three main characteristics: engages students as stakeholders in a problem situation; organizes curriculum around a given holistic problem, enabling student learning in relevant and connected ways; creates a leaming environment in which teachers coach student thinking and guide student inquiry, facilitating deeper levels of

\footnotetext{
${ }^{27}$ Toid.
}

${ }^{28}$ Lev S. Vygotsky, Mind in Society: The Development of Higher Psychological Processes (Cambridge: Harvard University Press, 1978).

${ }^{29}$ Ibid., 86. 
understanding. ${ }^{" 30}$ The following is a three-phased PBL instructional model, designed to promote advanced cognitive skills among U.S. history survey students. ${ }^{31}$

\section{Phase 1: Problem Development}

The problem-based learning cycle begins when students confront an authentic illstructured problem from U.S. history presented through a scenario or situation that directly involves students as stakeholders.

\section{Phase 2: Initiation of PBL Events, Inquiry, and Investigation}

Problem-based learning begins when students can define the problem, identify its multidimensional or multi-truth characteristics, identify the need for domain specific processes (historical inquiry and others ) and broad thinking systems (intuitive, formal, relativistic, and dialectical), build hypotheses that launch an investigation, and identify what they already know and what they need to know in order to develop solution alternatives.

\section{Phase 3: Problem Solution}

Students generate possible solutions or decisions and examine their "fit," propose the most appropriate one, and evaluate its historical or potential consequences. A final performance assessment and debriefing occur during this phase to help students construct their understanding of concepts and skills encountered and practiced during the problem-solving cycle and to reflect on the types of thinking strategies they used, and the successes or failures of each.

A sample-based U.S. history survey course on America since 1890 includes ten primary instructional topics/units, six of which include culminating PBL activities. Each activity takes approximately three 75 -minute class periods to complete. The course concludes with a PBL-based current issue student presentation.

- Unit 3: "The U.S. as an Empire: Global Power Structure (1890-1905)," PBL Activity - "The Question of U.S. Expansion: Expansionists versus AntiExpansionists."

- Unit 5: "The Nation at War," PBL Activity-Wilson and the Paris Peace Conference: Constructing the Treaty of Versailles."

- Unit 6: "Economic Expansion of the 1920s, The Depression, Franklin D. Roosevelt and the New Deal," PBL Activity-Solving the Problems of Depression: Constructing the New Deal."

\footnotetext{
${ }^{30}$ Linda Torp and Sarah Sage, Problems as Possibilities: Problem-Based Learning for K-16 Education, $2^{\text {nd }}$ ed. (Alexandria, VA: ASCD, 2002), 15.

${ }^{31}$ Adapted from Wynn, "Promoting Postformal Thought."
} 
- Unit 7: "America and the World (1921-1945)," PBL Activity—The Atomic Bomb: Truman's Decision and Its Impact."

- Unit 9: "Civil Rights in the U.S.: Tracing Social, Economic, and Political Dynamics in the Last Half of the $20^{\text {th }}$ Century," PBL Activity- "The Issue of Affirmative Action: The Atlanta Case."

- Unit 10: "Challenges of the New Century," PBL Activity-_" Student Current Issue Presentation. ${ }^{932}$ (Students follow a presentation format based on a relativistic/dialectical problem-solving model.)

The following is a description of the PBL activity for Unit 5 on "Wilson and the Paris Peace Conference: Constructing the Treaty of Versailles." "33 An expanded description of each of the three PBL phases follows (italicized), including a description of how specific procedures from the activity fit within each phase. The other five PBL activities above follow this three-phase model.

Phase 1 - The problem-based learning cycle begins when students confront an authentic ill-structured problem from U.S. history presented through a scenario or situation that directly involves students as stakeholders. Introduction of Problem or Issue-Instructors should create a "need to know" as the problem is introduced through a case study, a story, data, video clips, etc., to help students gain a conceptual understanding of the problem, and to personalize the problem or issue. Creating an intrinsic motivation or student ownership of the problem is the goal. The problem should be authentic and ill-structured. The activity should be designed to reflect the complexity of the problem and to provide an authentic setting for problem-solving and decision-making.

\section{Problem Introduction}

The problem is introduced by reading the following scenario to students: "It is January, 1919. President Woodrow Wilson is in France to join the 26 other victorious nations at the Paris Peace Conference to help construct a final settlement of the war that ended in November 1918. Two million people lined the Champs-Elysees to welcome, cheer, and greet Wilson. A year earlier Wilson had outlined key principles (Fourteen

\footnotetext{
${ }^{32}$ Groups of students are assigned current issue presentation topics after participating in a brief overview of social, political, economic, and foreign policy challenges facing the U.S. from 2000 to the present, i.e. health care reform; debt reduction, federal spending, entitlements, and taxes; immigration reform; energy policy; post-September 11, 2001, foreign policy challenges, etc. This activity explicitly connects students' individual and collective postformal problem-solving capacity to the types of problems and issues they might encounter as citizens. Readers interested in attaining the presentation guide and grading rubric may do so by contacting the author at cwynn6@kennesaw.edu.
}

\footnotetext{
${ }^{33}$ The full activity, including detailed procedures, materials, assessments, rubrics, and Power Point slides, may be accessed at http://tinyurl.com/wynnpbl2.password: PBL2.
} 
Points) on which a lasting peace could be based in a speech to the U.S. Congress. His reception in Paris convinced him that the people of Europe and its leaders shared the goals outlined in his Fourteen Points. However, there was a great deal of tension and disagreement between the major Allied powers (France, Britain, and U.S.) as the Conference opened."

This "problem introduction" is followed by a five-minute clip from The American Experience outlining these tensions. ${ }^{34}$ The instructor then states the following: "With these tensions and disagreements in mind, you are going to participate in a simulation of the 1919 Paris Peace Conference and construct your own treaty. You will be assigned a role within one of four groups: French Delegation, British Delegation, U.S. Delegation, and the German Group (not present at the Conference in 1919 but included in the activity). You will ultimately compare your treaty provisions with those of the Treaty of Versailles."

Phase 2 - Initiation of PBL Events, Inquiry, and Investigation: Problem-based learning begins when students can define the problem and identify its multidimensional, or multi-truth characteristics, build hypotheses that launch an investigation, and identify what they already know and what they need to know in order to develop solution alternatives. Evaluation of Problem or Issue-Instructors guide students in recognizing the multidimensional nature of the problem or issue, including: (a) that multiple perspectives or opinions are in play, (b) that there are multiple, and possibly opposing solution alternatives to the problem or issue, (c) that various values, opinions, and beliefs back multiple positions and solution alternatives. Students then gather and apply relevant information as they construct solution alternatives and supporting explanations.

\section{Evaluation of Problem or Issue}

Following the introduction, the instructor uses PowerPoint slides to guide students to construct a contextual overview of the opening of the Paris Peace Conference following the outline below.

A. Wilson's Plan for a Lasting Peace

1. January 1918 Speech to U.S. Congress (primary document) ${ }^{35}$

2. Wilson's Perception of the Peace Conference and His Role, January 1919

B. The French Perspective of the Paris Peace Conference

\footnotetext{
${ }^{34}$ The American Experience, "Woodrow Wilson" (WGBH/Boston, 2003). Available from http://www.youtube.com/watch?v=RQXBGLrtqx 8 (accessed December 27, 2012). The five-minute clip is from $45: 20$ to $50: 23$.

${ }^{35}$ Firstworldwar.com, Primary Documents 1918, "Woodrow Wilson's Fourteen Points' Speech, 8 January 1918," http://www.firstworldwar.com/source/fourteenpoints.htm (accessed December 27, 2012).
} 
1. The Costs of the War

2. Remembering the Franco-Prussian War and the Versailles Conference, 1871

C. Tension as the Conference Opens

1. Sisley Huddleston's Account of the Opening of the Paris Peace Conference, January 18, 1919 (primary document) ${ }^{36}$

2. Student Summary of the Context at the Opening of the Paris Peace Conference

After the contextual overview, the instructor divides the class into four groups: Group 1 (French Delegation), Group 2 (British Delegation), Group 3 (U.S. Delegation), Group 4(German Group), and distributes each group's handout: Goals of Clemenceau and the French Delegation, Goals of Lloyd George and the British Delegation, Goals of Wilson and the U.S. Delegation, and the German Perspective at Versailles. The instructor guides students through each handout and contrasts the German expectation going into the Conference that Wilson's key principle of peace among equals would be followed with the attitude and goals of the French and British. The instructor states that the primary task of the U.S., French, and British Groups is to construct a ten-minute presentation outlining what they believe should be the fundamental provisions of the treaty and why these provisions should be included. The instructor also encourages each group to be as persuasive as possible in its attempt to convince the other groups to agree to its key goals/provisions. The remainder of class time is used to plan the presentations that will be shared during the next class session. The instructor provides the German group Count von Brockdorff-Rantzau's letter to Paris Peace Conference President Georges Clemenceau on the subject of peace terms, May $1919,{ }^{37}$ adding a brief explanation that they should read the letter with specific attention to German Conference expectations and the German perspective on accepting blame for the war. The German group members then make a list of what they would consider to be the most objectionable potential treaty provisions. The instructor informs the German Group that they can only sit and listen-they cannot participate or respond to the Allies' presentations since there was no German delegation at the Conference. As the class session ends, the instructor asks the Allied groups to complete their presentations prior to the next class and to make sure that each group member participates, and lastly tells the class that there will be a five to ten-minute preparation period at the beginning of the next class.

\footnotetext{
${ }^{36}$ Firstworldwar.com, Primary Documents, 1919, "Sisley Huddleston's Account of the Opening of the Paris Peace Conference, 18 January 1919," http://www.firstworldwar.com/source/parispeaceconf_ huddleston.htm (accessed December 27, 2012).
}

${ }^{37}$ Firstworldwar.com, Primary Documents, 1919, "German Delegates' Protest Against Proposed Peace Terms at the Paris Peace Conference, May 1919," http:www.firstworldwar.com/source/parispeaceconf germanprotesti.htm (accessed December 27, 2012). 
Phase 3 - Problem Solution: Students generate possible solutions and examine their "fit," and propose the most appropriate one. A final performance assessment and debriefing also occur during this phase to help students construct their understanding of concepts and skills encountered and practiced during the problem solving cycle and to reflect on the types of thinking strategies they used, and the success or failure of each. Decision-making and Debriefing-Students construct solution alternatives based on information gathered and presented, and select the best solution. If a group decision is made, students should be given the opportunity to make and support a personal decision. An individual presentation or essay assignment provides students an opportunity to share their perspective, and provides a valid assessment opportunity. Instructors should debrief the activity to help students connect their problem-solving experience to specific content knowledge and skills gained and applied during the activity, and to help students reflect on the cognitive operations they used.

\section{Problem Solution}

After a brief preparation period, the instructor directs the French, British, and U.S. Delegations to present their proposals based on the guidelines provided in their respective handouts and explains that each group will present uninterrupted. After each group has presented and listed its provision proposals, the instructor facilitates negotiations among the three groups as they identify terms and provisions to include in the treaty to be presented to the German Group. After considering the terms of the allied treaty, the German Group constructs a written counter-proposal (based in part on the Count von Brockdorff-Rantzau's letter). The Allies read Georges Clemenceau's letter of reply to the objections of the German Peace Delegation, May $1919,{ }^{38}$ while the German Group deliberates and constructs a counter-proposal. Once the German counter-proposal is received, the instructor prompts the members of each Allied group to explain their rejection of any German counter-proposals and to provide a rationale for specific punitive provisions (usually offered by French and British Delegations), or more lenient or unilateral provisions (usually offered by the U.S. Delegation) as they hash out a final treaty to present to the German Group.

Once the final treaty is presented to the Germans, the instructor explains that Germany was given a three-week deadline to sign the Treaty in 1919. Therefore, only three minutes is allotted for German consideration. The German Group may ask "What happens if we do not sign?" The instructor should turn to the Allies for a response, suggest that they refer to the last page of Clemenceau's letter of reply, and read aloud his final statement: "The said armistice will then terminate, and the Allied and

\footnotetext{
${ }^{38}$ Firstworldwar.com, Primary Documents 1919, “Allied Reply to German Delegates' Protest Against Proposed Peace Terms at the Paris Peace Conference, May 1919," http://www.firstworldwar.com/source/ parispeaceconf_germanprotest2.htm (accessed December 27, 2012).
} 
Associated Powers will take such steps as they think needful to enforce their terms. ${ }^{n 39}$ After the German Group signs, or refuses to sign, the treaty, the instructor shows the primary provisions of the Treaty of Versailles from the PowerPoint Slides, and then asks students to compare the provisions of their treaty with the provisions of the actual Treaty of Versailles. The instructor guides students to compare a 1914 map of Europe with a 1919 post-Versailles map of Europe (using PowerPoint slides or a good historical atlas), with attention to lands taken from Germany and the newly constituted nations in which ethnic mixtures could lead to future conflicts, and then distributes the following essay question as a take-home assignment, which is due the next class session: "If you had been a delegate at the Paris Peace Conference in 1919, would you have supported a harsh or lenient treatment of Germany? Compare your perspective on this issue with the French, British, and U.S. perspective at Versailles. Lastly, in hindsight, was Wilson right? Why or why not? Your essay should include primary source citations and endnotes to support your argument."

The instructor uses the remainder of the class to debrief and summarize the activity by asking members of the German Group how they view the provisions of the actual Treaty and to describe their attitude toward the Allies. Then the instructor asks the class the following questions: Do you believe the European Allies felt vindicated by the Treaty? Why? Do you believe the European Allies felt safer as they looked toward the 1920s? Why? Which provisions of the Treaty would be most objectionable to the U.S.? Do you believe most Europeans thought the Treaty would bring peace and stability to Europe? After students have responded, the instructor shares excerpts from a June 1919 Algemeen Handelsblad editorial against the terms of the Paris Peace Conference, ${ }^{40}$ asks students to speculate on how a French nationalist might have responded to the editorial, and then explains that the class will explore how the punitive provisions of the Treaty affected the political and economic conditions in Germany during the 1920s and the rise of radical groups on both the right (Nazis) and left (Communists), which will be a focus of Unit 7: America and the World (1921-1945). The instructor dismisses the class after a brief preview of the next session which will include an examination of why and how the Treaty of Versailles was rejected by the U.S. Senate and a review of the thinking dynamics students utilized during the Paris Peace Conference activity.

Reflection: Students reflect on the types of thinking strategies they used and the successes or failures of each.

${ }^{39}$ Tbid., last paragraph.

${ }^{40}$ Firstworldwar.com, Primary Documents 1919, "Dutch Newspaper Editorial Against the Terms of the Paris Peace Conference, May 1919," http://www.firstworldwar.com/source/parispeaceconf dutcheditorial.htm (accessed December 27, 2012). 
The instructor continues the debriefing during this phase to help students recognize their understanding of content, concepts, and skills utilized during the Paris Peace Conference activity and to reflect on the thinking strategies they used. The instructor guides students to identify specifically the thinking operations they utilized during the activity (intuitive, formal, relativistic, dialectical, discipline specific) and estimate how useful these processes were in helping them recognize the multidimensional nature of the issue, along with multiple truths or perspectives that were considered during the construction and selection of solution/decision alternatives. The instructor explains the cognitive dynamics associated with each thinking system early in the semester as a means of scaffolding or modeling cognitive reflectivity, which in turn prompts students to recognize and reflect on the thinking strategies they used. Students are able to complete this process independently as the semester progresses as they gain experience in cognitive reflection and in the application of diverse cognitive operations associated with problem-based learning. ${ }^{41}$

\section{Implications}

Instructors should be aware of several factors when considering the use of problem-based activities in a U.S. history survey course. The social learning dynamics of problem-based activities require a large enough class (at least ten to twelve students) to ensure a diversity of opinions and perspectives. However, the class must be small enough (perhaps forty students or fewer) to support successful group dynamics. A chronological coverage approach must be adapted to accommodate a workable number of problem-based activities. A "less is more" instructional mindset helps in this regard, based on the rationale that problem-based learning creates an environment in which students construct deeper understandings and gain applicable domain specific and broader advanced cognitive skills. Instructors must be open and tolerant of multiple viewpoints and opinions on problems and issues, and must avoid guiding students toward a "preferred" position or opinion. Any bias must be suspended as faculty model and guide students in the practice of relativistic and dialectical reasoning. Failure to do so might deny students the opportunity to gain experience in dialectical thinking. ${ }^{42}$

Significant research needs to be conducted to determine the impact of problembased learning activities on the cognitive development of survey history students. These studies should examine specifically whether or not participation in multiple problem-based learning activities with guided reflection significantly enhances postformal thinking.

\footnotetext{
${ }^{41}$ Readers interested in attaining a cognitive reflection questionnaire that guides the reflective process may do so by contacting the author at cwynn6@kennesaw.edu.
}

${ }^{42}$ Wynn, "Promoting Cognitive Growth." 


\section{Conclusion}

Building from learning theory and the challenges that learning theory poses for survey courses in history, the instructional framework presented in this article is one option that U.S. survey instructors might utilize in guiding students to analyze primary sources purposefully and develop and apply postformal cognitive operations within a broader problem-solving/issue-based context. These PBL experiences are designed to help bridge the individual and collective gaps described by Inglis and Steele and might serve to promote a social action outcome as posited by Carole Hahn: "When students themselves engage in the process by which public issues are resolved in a democracy, they seem to develop the will to participate in civic life in ways that do not occur when they passively hear about the history of democratic ideals and institutions." ${ }^{34}$ These PBL experiences also serve to guide students toward the development of thinking systems that might help them deal with the personal contradictions, inconsistencies, and changes they will face in their lives far beyond the confines of their survey history course.

${ }^{43}$ Carole L. Hahn, "Controversial Issues in History Instruction," in Cognitive and Instructional Processes in History and the Social Sciences, ed. Mario E. Carretero and James F. Voss (Hillsdale, NJ: Lawrence Erlbaum Associates, Inc., 1994), 204. 